\title{
Nebulised drugs in palliative care
}

\author{
S Ahmedzai, C Davis
}

Palliative care is now generally accepted as being the multidisciplinary care of patients with advanced, progressive, and ultimately fatal diseases which are likely to lead to death within about 12 months and in whom the focus of care is on the quality of life. Most of the patients who fall into this category have metastatic malignancy, but it also includes those with motor neurone disease and other neuromuscular conditions, HIV/AIDS, end stage carmuscular conditions, HIV/AIDS, end stage car-
diac or respiratory failure, and renal failure. Palliative care is given in the community in the UK by general practitioners and district nurses, and in hospitals by staff from several disciplines, notably oncology/radiotherapy and general/respiratory medicine. The term "specialist palliative care" is reserved for the "specialist palliative care" is reserved for the
involvement of hospices, or trained and acinvolvement of hospices, or trained and ac-
credited medical and nursing teams in hospitals and the community (including day centres). Many specialist palliative care teams have access to physiotherapy, although this is less likely to be available in the community.

The general condition and age of the patients and, in general, the lack of training in respiratory management among palliative care staff mean that, in this clinical setting, some points need particular attention.

In the setting of palliative care the main conditions which might benefit from nebuliser therapy are dyspnoea, cough (both unproductive and with copious sputum), and pooling of saliva in the hypopharynx and consequent aspiration, such as occurs in patients sequent aspiration, such as occurs in patients
with motor neurone disease or bulbar palsy. ${ }^{1}$ with motor neurone disease or bulbar palsy. ${ }^{1}$
History and clinical examination are of vital importance in establishing the most likely pathological causes of breathlessness in each patient. A chest radiograph can also be helpful but it is not always possible or appropriate to perform one.

There is very little scientific evidence to support the use of nebulised drugs in the symptomatic management of patients with breathlessness and/or cough related to primary or secondary malignancy (table 1), or in chronic cardiac and neuromuscular disorders. Doses and schedules have been partly derived from experience in patients with chronic lung disease but mainly empirically from practitioners' experiences.

In the setting of palliative care it is easy to commence drug therapy but much harder to discontinue it. Ideally, a therapeutic trial should be conducted but it is difficult to generalise and propose a fixed duration of such a trial. However, we recommend that all newly initiated treatments should be considered as therapeutic trials and be reviewed by experienced peufic tring and be can be made or treatment stopped. It is not usually appropriate to ask the primary care team to review if treatment with a nebulised opioid or a local anaesthetic has been started.

\section{Practical considerations}

Particle size may not be as critical as it is in some other situations but, nonetheless, clinicians must be aware of the range of compressors and nebulisers available and the variation in their performance. A jet nebuliser driven by an electric/battery operated compressor is usually appropriate.

Patients with a short history of breathlessness sometimes prefer a mouthpiece to a mask which can generate a feeling of claustrophobia. If a mouthpiece is used the patient must breathe through the mouth. Nebulised drugs are usually ineffective in extremely breathless patients with minimal inspiratory effort. The position of the patient is important. He or she should be sitting upright or at least at $45^{\circ}$ during from the supine position then adm

Table 1 Nebulised drugs used in patients with cough and/or breathlessness related to cancer

\begin{tabular}{|c|c|c|c|}
\hline Class of drugs & Indication & Scientific evidence & Comments \\
\hline Normal saline & Loosening of tenacious secretions & None & \multirow{4}{*}{$\begin{array}{l}\text { Probably underemployed in this } \\
\text { setting. May also help breathlessness } \\
\text { May result in copious liquid sputum } \\
\text { which the patient may still not be able } \\
\text { to cough up } \\
\text { Very limited clinical experience only. } \\
\text { May not be more beneficial than use } \\
\text { of inhaler and spacer } \\
\text { Appreciable risk of bronchospasm. } \\
\text { Reduces sensitivity of gag reflex }\end{array}$} \\
\hline $\begin{array}{l}\text { Mucolytic agents e.g. hypertonic } \\
\text { saline, acetylcysteine }\end{array}$ & To thin viscous sputum & Conflicting evidence & \\
\hline Steroids e.g. budesonide & $\begin{array}{l}\text { Possibly in stridor, lymphangitis, } \\
\text { radiation pneumonitis and cough after } \\
\text { insertion of stents }\end{array}$ & None & \\
\hline $\begin{array}{l}\text { Local anaesthetics e.g. lignocaine, } \\
\text { bupivacaine }\end{array}$ & $\begin{array}{l}\text { Possible non-specific effects on } \\
\text { breathlessness. May be useful in some } \\
\text { cases with cough, particularly soly } \\
\text { lymphangitis }\end{array}$ & $\begin{array}{l}\text { Conflicting evidence: dyspnoea, }{ }^{2-5} \\
\text { cough }^{6}\end{array}$ & \\
\hline $\begin{array}{l}\text { Opioids e.g. morphine, diamorphine, } \\
\text { fentanyl }\end{array}$ & $\begin{array}{l}\text { Non-specific effect on breathlessness, } \\
\text { possibly more likely to be of benefit in } \\
\text { diffuse lung disease }\end{array}$ & Conflicting evidence ${ }^{7-14}$ & \multirow{2}{*}{$\begin{array}{l}\text { Optimal dose schedule and relative } \\
\text { efficacy unknown. Needs comparison } \\
\text { with opioids administered by other } \\
\text { routes. Risk of bronchospasm } \\
\text { Probably overemployed since will not } \\
\text { help fixed airflow obstruction due to } \\
\text { local tumour. }\end{array}$} \\
\hline Bronchodilators e.g. salbutamol & $\begin{array}{l}\text { Treatment of reversible airway } \\
\text { obstruction }\end{array}$ & $\begin{array}{l}\text { Extrapolated from patients with } \\
\text { asthma and COPD }\end{array}$ & \\
\hline
\end{tabular}


drugs by this route is impractical and probably inappropriate.

Nebulisers are being used increasingly in palliative care settings which do not have the infrastructure for a nebuliser service. Some practical considerations can be overlooked. The following are essential: education of patients following are essential: education of patients
and carers; instruction on cleaning of equipment including "disposables"; a system that ensures regular maintenance and electrical safety of equipment; and arrangements for collection of the equipment after a patient's death. Doctors who prescribe nebuliser treatment at home or in hospices should consider collaborating with their local nebuliser service on these issues.

\section{Drugs used}

The drugs most commonly used in this setting are described in table 1 . Since the use of nebulised local anaesthetics and nebulised opioids is largely peculiar to palliative care, these interventions are discussed in more detail below.

NEBULISED LOCAL ANAESTHETICS

One study showed a ventilatory stimulant effect in normal volunteers ${ }^{2}$ but studies to date do not support the use of nebulised local anaesthetics for breathlessness in patients with chronic obstructive pulmonary disease (COPD). ${ }^{34}$ In a recent randomised study of palliative care, patients with cancer showed no benefit from nebulised lignocaine compared with normal saline..$^{5}$ The only study to investigate the efficacy of local anaesthetics in the treatment of cough showed encouraging results $^{6}$ and there are unpublished anecdotal reports of its use in patients with cough of various causes (table 1). A dose of nebulised local anaesthetic before retiring at night can be very helpful in reducing cough stimulated by pooling of saliva in the hypopharynx of patients with motor neurone disease or multiple sclerosis but may increase the risk of aspiration. The relative merits of lignocaine and bupivacaine have not been assessed. The reduced sensitivity of the cough reflex means that patients should fast for one hour after treatment with a local anaesthetic. Bronchospasm is not uncommon and may be of delayed onset - that is, after repeated doses. The patient and his/her family must be warned of this potential complication and the first dose should be given in a supervised seting dose medical or nursing interpervised setting where medical or nursing intervention is available if necessary. The treatment
should be reviewed regularly. In asthmatic patients it may be useful to prescribe a bronchodilator routinely before treatment.

NEBULISED OPIOIDS

Nebulised opioids are used to improve patien care but only one paper has been published to support the use of nebulised morphine in breathless patients with $\mathrm{COPD}^{7}$ and these findings were not substantiated in two subsequent studies. ${ }^{89}$
There is increasing anecdotal evidence to support their use in patients with breathlessness related to cancer, ${ }^{1}$ and it has been suggested that patients with lymphangitis are most likely to derive benefit. However, a recent randomised placebo controlled trial failed to show a significant effect, although some patients may benefit. $^{10}$

Various opioid drugs have been used ${ }^{11}$ of which morphine and diamorphine are the most common; fentanyl may be associated with less bronchospasm. ${ }^{1}$ Morphine 6-glucuronide, codeine and hydromorphone have also been used. None of these drugs is licensed for administration by nebuliser in the UK.

For all these drugs there is no consensus on the most appropriate starting dose or schedule, the best steps for dose titration, or on the optimal design and length of a therapeutic trial. It is usually assumed that equianalgesic doses of different opioids will have similar effects on the the symptom of breathlessness, but there is scientific evidence to support this premise.

The pharmacokinetics of nebulised opioids have been investigated. ${ }^{1213}$ There is some evidence that the bioavailability of nebulised morphine in normal volunteers is very low $(<5 \%)$ relative to the intravenous route. ${ }^{14}$ It is, however, dangerous to assume that this is always the case because the systemic bioavailability the case because the systemic bioavailability of any nebulised drug can vary considerably depending on the equipment used and the degree of inspiratory effort of which the patient is capable. Thus, the simultaneous use of both nebulised and oral or subcutaneous opioids may carry a risk of cumulative toxicity proportional to the dose of nebulised opioid administered.

Nebulised opioids are unlikely to have a place in the management of pain and, in any case, the oral, rectal and subcutaneous routes are more appropriate. There is a risk of bronchospasm, particularly with higher doses. The first dose should always be administered in a supervised setting where medical or nursing interpervised setting where medical or nursing intervention is avallable in case of bronchospasm or other adverse effect. Some, but not all, clinicians use preservative-free opioid preparations in an attempt to reduce the risk of bronchospasm. If morphine is employed then the intravenous formulation should be used and not the oral elixir.

In the domiciliary setting the problems of preparation of the nebuliser solution (use of controlled drugs in glass vials, need to mix with saline) should not be underestimated. Diffculties may arise if patients travel on holiday (especially abroad) and need to take a nebuliser and opioid ampoules - a letter of authorisation should be given and an adequate supply dispensed before departure.

\section{Further research}

There are several areas where our knowledge about nebuliser usage in palliative care is weak or altogether lacking. It is cause for concern that many teams and units worldwide are using nebuliser therapy increasingly, and possibly uncritically, while the evidence for benefit from the 
Table 2 Current "best clinical practice" for the use of nebulised drugs in palliative care

\begin{tabular}{|c|c|c|c|c|}
\hline Indication & Drug & Starting dose/schedule & Dose titration & Special points \\
\hline $\begin{array}{l}\text { Tenacious secretions } \\
\text { Reversible airflow obstruction }\end{array}$ & $\begin{array}{l}\text { Normal saline } \\
\text { Salbutamol } \\
\text { Terbutaline }\end{array}$ & $\begin{array}{l}5 \mathrm{ml} 6 \text { hourly } \\
2.5 \mathrm{mg} 4-6 \text { hourly }\end{array}$ & $\begin{array}{l}\text { Up to } 2 \text { hourly } \\
\text { Up to } 5 \mathrm{mg} 4 \text { hourly } \\
\text { Un to } 10 \mathrm{mg} 4 \text { hourly }\end{array}$ & $\begin{array}{l}\text { Risk of sensitivity to cardiac } \\
\text { stimulant effects }\end{array}$ \\
\hline Stridor & $\begin{array}{l}\text { Budesonide* (in conjunction } \\
\text { with other appropriate }\end{array}$ & $0.5 \mathrm{mg} 12$ hourly & Up to $1 \mathrm{mg} 12$ hourly & $\begin{array}{l}\text { Risk of oral candidiasis; rinse } \\
\text { mouth after use }\end{array}$ \\
\hline Cough & $\begin{array}{l}2 \% \text { lignocaine* } \\
0.25 \% \text { bupivacaine* }\end{array}$ & $\begin{array}{l}5 \mathrm{ml} \mathrm{prn} \\
5 \mathrm{ml} \mathrm{prn}\end{array}$ & $\begin{array}{l}\text { Up to } 6 \text { hourly } \\
\text { Up to } 8 \text { hourly }\end{array}$ & \multirow{2}{*}{$\begin{array}{l}\text { Risk of bronchospasm } \\
\text { Fast for one hour after } \\
\text { nebulisation } \\
\text { Risk of bronchospasm } \\
\text { (reduced with fentanyl) }\end{array}$} \\
\hline Breathlessness & $\begin{array}{l}\text { Morphine sulphate* } \\
\text { Diamorphine* } \\
\text { Fentanyl* }^{*}\end{array}$ & 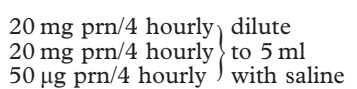 & $\begin{array}{l}\text { Up to } 100 \mathrm{mg} 4 \text { hourly } \\
\text { Up to } 100 \mathrm{mg} 4 \text { hourly } \\
\text { Up to } 100 \mu \mathrm{g} 2 \text { hourly }\end{array}$ & \\
\hline
\end{tabular}

* Not licensed indication.

potent drugs being used is as yet predominantly anecdotal. Many of the studies so far published have concentrated on single doses of drug, and have tended to focus on objective and possibly irrelevant functional improvements rather than validated and clinically meaningful subjective and quality of life indicators. Longitudinal studies are, however, difficult to perform in this population of patients since their clinical condition often changes rapidly and attrition rates are high.

Recommendations for best clinical practice

Our recommendations are presented in table 2 .

1 Ahmedzai S. Palliation of respiratory symptoms. In: Doyle palliative medicine. Oxford: Oxford University Press, 1993. $34-78$.
Winning Aamilton RD, Guz A. Ventilation and breath2 Winning AJ, Hamilton RD, Guz A. Ventilation and breath-
lessness on maximal exercise in patients with interstitial Sci 1988;74:275-81.
Stark RD, O'Neill PA, Russell NJW, Heapy CG, Stretton on dyspnoea in patients with respiratory disease. $\mathrm{Clin} S \mathrm{Si}$

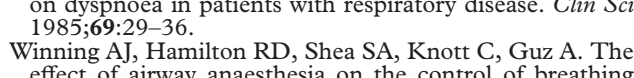
and the sensation of breathlessness in man. Clin Sci 1985, 68:215-25.
Wilcock A. Corcoran R, Tattersfield AE. Safety and efficacy Wilcock A, Corcoran R, Tattersfield AE. Safety and efficacy
of nebulised lignocaine in patients with cancer and breathlessness. Palliat Med 1994;8:35-8. SR et al. Lignocaine Howard P, Clayton RM, Brennan SR, et al. Lignocaine
aerosol and persistent cough. Br I Dis Chest 1977;71: Young IH, Daviskas E, Keena VA. Effect of low dose nebulised morphine on exercise endurance in patients Beauford W, Saylor TT, Stansbury DW, Avaolos K, Light RW. Effects of nebulised morphine sWlate on the exercis tolerance of the ventilatory $104: 175-8$. Masood AR, Reed JW, Thomas SHC. Lack of effect of thaled morphine on exercise-induced breathlessness in 629-34. Davis CL, Penn K, R A'Hern, Daniels J, Slevin M. Single dose randomised controlled trial of nebulised morphine in patients with cancer-related breathlessness. Palliat Med Farncombe M, Cater S, Gillin A. The use of nebulised
opioids for breathlessness: a chart review. Palliat Med 1994;8:306-12. Master N, Heap G, Wedly J, Moore A. Inhaled nebulised
morphine and diamorphine: useful in general practice? morphine and diamorphine: useful in general practice?
Practitioner 1988;2:

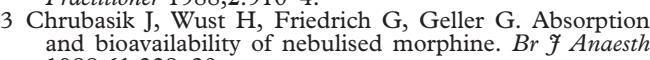
1988,61:228-30. DL. The pharmacokinetics of nebulised morphine. Pro-
Mavis ceedings of Intermational Association for the Study of Pain.
Seattle: IASP Publications, 1993: 379 (abstract 995). 